\title{
Standardized ileal digestible threonine requirement for broilers
}

\author{
J.W. Spek \\ Wageningen Livestock Research
}

CVB Documentation report nr. 64 June 2018

Wageningen Livestock Research

P.O. Box 338

$6700 \mathrm{AH}$ Wageningen

The Netherlands 


\section{ㄷ Federatie Nederlandse Diervoederketen 2017}

No part of this edition may be copied, photocopied, reproduced, translated or reduced to any electronic medium or machine-readable form, in whole or in part, without specific written permission of the Federatie Nederlandse Diervoederketen (info@diervoederketen.nl).

All copyrights and database rights with respect to this publication are expressly reserved. Nothing in this publication may be reproduced, copied, retrieved, made public or re-used or made available in any way whatsoever to third parties by way of printing, photocopying, microfilm or in any other way unless the Federatie Nederlandse Diervoederketen has given express written permission to do so. This publication has been compiled with great care; however, the Federatie Nederlandse Diervoederketen and Wageningen Livestock Research cannot be held liable in any way for the consequences of using the information in this publication. 


\section{Preface}

In 2017 a new Table has been introduced called; Table 'Standardized ileal digestibility of amino acids in feedstuffs for poultry' and has been described in the CVB Documentation report nr. 61 . As a feed evaluation system has two pillars - the supply of nutrients by the diet on the one hand and the requirement for these nutrients by the animals on the other hand (both expressed in the same units) - it was also necessary to also update and express the amino acid requirements on a standardized ileal digestibility (SID) basis.

Therefore a large meta-analysis dataset was constructed from studies in which amino acid requirements in broilers were estimated. The SID amino acid concentrations of the diets used in the studies were recalculated based on the new CVB SID amino acid Table (CVB Documentation report nr. 61) and requirements of SID amino acids were subsequently estimated. The results of this meta-analysis for standardized ileal digestible threonine (SIDTHR) are presented in the present CVB Documentation report. Compared to the former CVB apparent faecal digestible THR recommendation for broilers described in CVB Documentation report nr. 18 and published in 1996 the present established SID-THR amino acid recommendations for broilers are:

1. Based on a substantial larger dataset of requirement studies

2. Based on studies with modern broiler types in the period $1990-2017$

3. Based on standardized ileal digestible amino acid values in feedstuffs instead of apparent faecal digestible amino acid values.

The in this report estimated requirement of SID-THR will be incorporated in the Dutch CVB Tabellenboek Veevoeding Pluimvee 2018 and in the English version CVB Table Poultry Nutrition 2018.

This study was guided and assessed by the Technical Committee of CVB

Wageningen, June 2018

J.W. Spek 


\section{Members of the Technical Committee of the CVB}
M. Rijnen (chair)
J. Fledderus
B. Boswerger
A. Dijkslag
H. van Laar
K. Geerse
D. van Manen
J. van der Staak
H. Korterink
A. van de Ven
C. van Vuure
G. van Duinkerken

J.W. Spek
Nederlandse Vereniging Diervoederindustrie (Nevedi) Nederlandse Vereniging Diervoederindustrie (Nevedi) Nederlandse Vereniging Diervoederindustrie (Nevedi) Nederlandse Vereniging Diervoederindustrie (Nevedi) Nederlandse Vereniging Diervoederindustrie (Nevedi) Nederlandse Vereniging Diervoederindustrie (Nevedi) Overleggroep Producenten Natte Veevoeders (OPNV) Land- en Tuinbouworganisatie Nederland (LTO) Nederlandse Vereniging van Handelaren in Stro, Fourages en Aanverwante Producten (HISFA) Nederlandse Vereniging Diervoederindustrie (Nevedi) MVO, ketenorganisatie voor oliën en vetten Wageningen Livestock Research, Dept. Animal Nutrition, Wageningen

Wageningen Livestock Research, Dept. Animal Nutrition, Wageningen 


\section{Contents}

Table of Contents $\quad$ Page

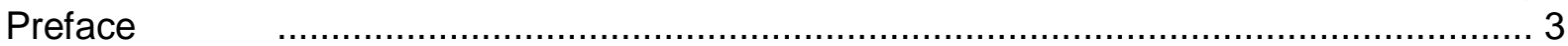

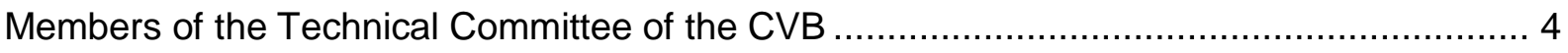

Contents $\quad$.

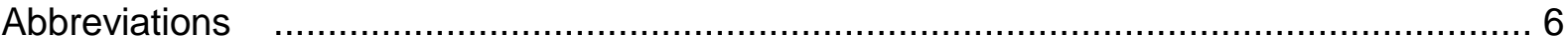

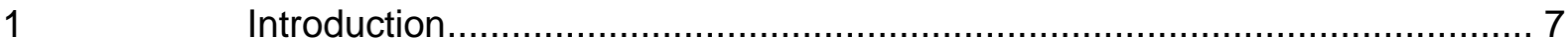

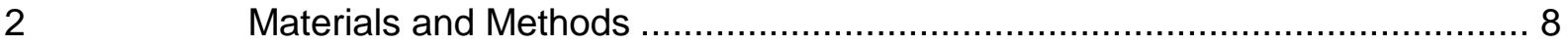

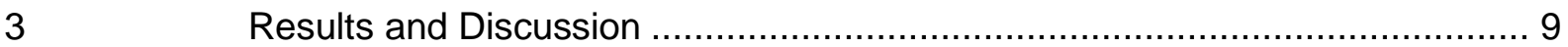

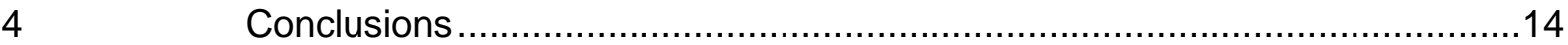

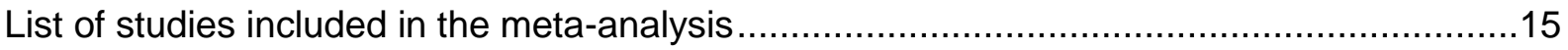

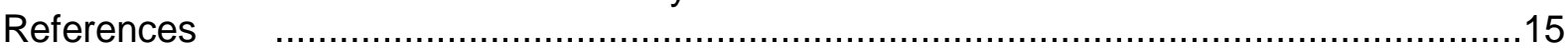

Appendix A. Relationship between dietary SID-THR supply and performance parameters

FCR and BWG for the various titration trials. ..........................................16

Appendix B. SID-THR model estimates using the quadratic broken-line model for minimum

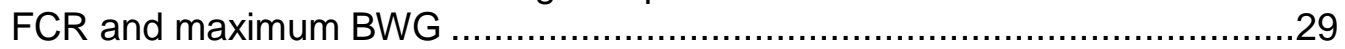




\section{Abbreviations}

$\begin{array}{ll}\text { AA } & \text { Amino acids } \\ \text { AFD } & \text { Apparent faecal digestible } \\ \text { ARG } & \text { Arginine } \\ \text { BWG } & \text { Body weight gain } \\ \text { CP } & \text { Crude protein } \\ \text { FCR } & \text { Feed conversion ratio } \\ \text { ILE } & \text { Isoleucine } \\ \text { LYS } & \text { Lysine } \\ \text { ME } & \text { Metabolic energy } \\ \text { MET } & \text { Methionine } \\ \text { M+C } & \text { Methionine plus Cysteine } \\ \text { N } & \text { Number } \\ \text { R } & \text { Coefficient of determination } \\ \text { Req } & \text { Requirement } \\ \text { SID } & \text { Standardized ileal tract digestible } \\ \text { Std. Dev. } & \text { Standard deviation } \\ \text { Std. Err. } & \text { Standard error } \\ \text { THR } & \text { Threonine } \\ \text { TRP } & \text { Tryptophan } \\ \text { VAL } & \text { Valine }\end{array}$




\section{Introduction}

In 2012 a large meta-analysis was carried out by Veldkamp and others in order to determine the dietary requirements for standardized ileal tract digestible (SID) amino acids (AA) for broilers. This study resulted in a report published by Veldkamp et al. (2016). Before the start of this meta-analysis by Veldkamp et al. another large meta-analysis was carried out in order to determine the SID-AA levels for the various feed ingredients. This meta-analysis resulted in a CVB table with SID-AA concentrations for the various feed ingredients and this Table was used by Veldkamp et al. (2016) in order to recalculate the dietary SID-AA levels for the individual AA titration studies in order to estimate AA requirements. However, in 2017 this CVB Table has been updated with new data published in the years between 2012 and 2017 as there were questions about the SID cysteine digestibility value for soybean meal. As a result, not only the SID-AA values for soybean meal have been updated but also for other feedstuffs. As a consequence it was necessary to recalculate all the diets used in the AA titration studies that Veldkamp et al. (2016) used to determine AA requirements. In this CVB documentation report the results of estimated dietary SID threonine (SID-THR; \%) requirements are presented that are based on the new Table values as presented in CVB documentation report nr. 61. Furthermore, the dataset used by Veldkamp et al. has been extended with new studies that were not included in the study of Veldkamp et al.. This resulted in a dataset that is substantially larger than the dataset used by Veldkamp. The SIDTHR requirements of the individual titration trials were estimated using a quadratic broken line model. This model was also used in estimation of SID-lysine requirements in the individual lysine titration trials as described in CVB documentation report nr. 62. 


\section{Materials and Methods}

Threonine titration studies were selected from literature $(1989-2017)$ in which only the dietary THR content was varied by means of addition of graded levels of dietary synthetic threonine. Furthermore, only those titration studies were selected in which non-test apparent digestible amino acid levels of the basal diet (diet with the lowest THR content) did not come below $10 \%$ of the recommended CVB (2012) levels and where dietary digestible THR levels of the basal diets where at least $20 \%$ below the recommended CVB (2012) level.

Furthermore, performance characteristics such as body weight gain (BWG: g/d) and feed conversion ratio (FCR; $g$ feed : $g$ BWG) had to be recorded and information with respect to dietary composition, sex, age of the broilers and duration of the experiment had to be provided in the studies.

Requirements were estimated using a quadratic broken-line model. The quadratic broken line model is as follows:

If $(\operatorname{SID}-\mathrm{THR}(\%)<\mathrm{R})$ then BWG or FCR $=\mathrm{L}+\mathrm{U} \times(\mathrm{R}-\mathrm{SID}-\mathrm{THR})^{\wedge 2}$; Else $B W G$ or $F C R=L+U \times 0$;

Where:

$\mathrm{L}=$ plateau value for $\mathrm{BWG}$ or $\mathrm{FCR}$

$\mathrm{R}=$ break-point value for SID-THR (\%)

$\mathrm{U}=$ slope value, representing the increase in BWG or decrease in FCR per unit increase in dietary SID-THR.

As THR requirements are normally expressed as a percentage of lysine (LYS) requirement the estimated SID-THR requirements of the individual THR titration trials were expressed as a percentage of SID-LYS level. The SID-LYS level was in a number of cases the SID-LYS level used in the THR titration studies. However, in a number of cases the SID-LYS levels used in the THR titration studies were larger than the SID-LYS requirements as predicted from the factors mean age of the birds and the dietary ME value as described in the prediction formulas F.5. and F.9. in CVB documentation report nr. 62. In those cases where the SID-LYS levels used in the THR titration studies were larger than the SID-LYS requirements as predicted from the prediction formula for SID-LYS requirements in CVB documentation report nr. 62 the predicted SID-LYS requirement levels using formulas F.5. (for BWG) and F.9. (for FCR) were used for the calculation of the SID-THR : SID-LYS ratios (SID-THR:LYS) of the individual experiments.

Via the PROC MIXED procedure of SAS the estimated SID-THR:LYS requirements for BWG and FCR were regressed against factors such as age, sex and the dietary factors CP, ME and $C P$ : ME ratio with study effect included as a random factor. Furthermore, non-test SIDAA : SID-LYS ratios were calculated and it was checked whether some of the non-test SID AA negatively affected the estimated SID-THR:LYS levels. 


\section{Results and Discussion}

In Table 1 a summary of the total dataset is given. The dataset consisted of 13 studies with in total 25 titration trials and 140 observations.

Table 1. Summary of the total dataset

\begin{tabular}{lrrrrr}
\hline & N & Mean & $\begin{array}{r}\text { Std. } \\
\text { Dev. }\end{array}$ & Minimum & Maximum \\
\hline ME Recalculated (kcal/kg) & 140 & 3110 & 131.1 & 2620 & 3238 \\
ME Publication (kcal/kg) & 140 & 3148 & 61.9 & 2945 & 3201 \\
CP Recalculated (\%) & 140 & 20 & 1.7 & 17 & 22 \\
CP Publication (\%) & 140 & 20 & 2.3 & 17 & 24 \\
Year & 140 & 2005 & 4.8 & 1996 & 2015 \\
Starting age (d) & 140 & 12 & 10.1 & 1 & 30 \\
Duration (d) & 140 & 18 & 3.7 & 6 & 21 \\
finishing age (d) & 140 & 30 & 11.9 & 7 & 42 \\
BWG (g/d) & 140 & 52.5 & 23.17 & 17.8 & 91.7 \\
FCR & 140 & 1.681 & 0.4026 & 1.060 & 4.160 \\
\hline
\end{tabular}

In Appendix A for each titration trial the relationship between dietary SID-THR supply and FCR between dietary SID-THR and BWG is presented graphically together with the estimated SID-THR requirements. In Appendix B the estimated quadratic broken-line model parameters for each titration trial is given.

For a number of titration trials ( 5 titration trials for FCR and 3 titration trials for BWG) it was not possible to estimate reliable or unique SID-THR requirements.

The estimated SID-THR:LYS requirement ratios for BWG and FCR were not significantly related to sex, age, dietary protein concentration, and dietary ME.

The average estimated SID-THR:LYS ratios for the remaining 20 SID-THR:LYS requirement observations for FCR and the 22 SID-THR:LYS requirement observations for BWG were:

SID-THR:LYS for BWG $=62.9 \pm 8.20 \%$ (average \pm Std. dev. $)$

SID-THR:LYS for FCR $=60.6 \pm 8.64 \%$ (average \pm Std. dev.)

Furthermore, there was one outlier SID-THR requirement estimate value that deviated more than two standard deviations from the average estimated SID-THR requirement estimate for both BWG and FCR. This was an observation from the study of Corzo et al. (2009). When removing this outlier value the average estimated SID-THR:LYS requirement ratios for the remaining 19 FCR trials and 21 BWG trials were:

SID-THR:LYS for BWG $=61.8 \pm 6.65 \%$ (average \pm St. dev.)

SID-THR:LYS for FCR $=59.6 \pm 7.38 \%$ (average \pm St. dev.)

There were some studies that contained a large number of titration trials whereas some studies contained only one titration trial. This results in average calculated SID-THR:LYS requirement ratios for BWG and FCR that are strongly influenced by the studies containing a large number of titration trials. In order to weigh the estimated SID-THR:LYS ratios from each study equally it is possible to take into account the effect of study. When this is done (using the PROC MIXED procedure of SAS and by including study as a random effect in the model) the estimated SID-THR:LYS ratios for BWG and FCR became:

SID-THR:LYS for BWG $=66.5 \pm 3.17 \%$ (estimate \pm St. error)

SID-THR:LYS for FCR $=63.7 \pm 3.01 \%$ (estimate \pm St. error) 
The exercise of estimating SID-THR:LYS requirement ratios for BWG and FCR in which each study is equally weighted was now repeated but in this case the outlier observation from the study of Corzo et al. (2009) was excluded. When this was done (by using the PROC MIXED procedure of SAS and including study as a random effect in the model) the estimated SID-THR:LYS requirement ratios for BWG and FCR became:

SID-THR:LYS for BWG $=64.4 \pm 2.67 \%$ (estimate \pm St. error)

SID-THR:LYS for FCR $=62.0 \pm 2.72 \%$ (estimate \pm St. error)

In Table 2 the dietary non-test SID-AA : estimated SID-LYS requirements ratios using the quadratic broken-line procedure for FCR and BWG are given together with the

recommended CVB apparent faecal digestible (AFD) ratios. Results in Table 2 show that on average the estimated SID-THR requirement estimates were not negatively impacted by limiting non-test AA levels although in a number of trials some non-test AA levels could have had a negative impact on estimated SID-THR levels as a comparison between recommended CVB ratios and minimal ratios for both FCR and BWG observed in this study show. However, a visual inspection of graphs in which the various AA:LYS ratios were plotted against estimated SID-THR:LYS requirement did not show that the low non-test SIDAA levels negatively impacted the estimated SID-THR:LYS requirements.

Table 2. Dietary non-test SID-AA : SID-LYS ratios.

\begin{tabular}{|c|c|c|c|c|c|c|c|c|c|}
\hline \multirow[b]{2}{*}{ Ratio } & \multirow{2}{*}{$\begin{array}{l}\text { Rec. } \\
\text { CVB } \\
\text { AFD } \\
\text { ratio }\end{array}$} & \multicolumn{4}{|c|}{ FCR } & \multicolumn{4}{|c|}{ BWG } \\
\hline & & Mean & St.dev & Min & Max & Mean & St.dev & Min & Max \\
\hline M+C:LYS & 65 & 78 & 5.6 & 71 & 95 & 80 & 5.3 & 75 & 100 \\
\hline TRP:LYS & 16 & 18 & 1.6 & 16 & 20 & 18 & 1.5 & 16 & 21 \\
\hline ILE:LYS & 66 & 69 & 3.8 & 64 & 77 & 70 & 4.1 & 64 & 79 \\
\hline ARG:LYS & 105 & 134 & 28.3 & 99 & 184 & 140 & 30.0 & 99 & 184 \\
\hline VAL:LYS & 80 & 79 & 5.2 & 68 & 95 & 81 & 5.2 & 68 & 100 \\
\hline
\end{tabular}

It furthermore appeared that the estimated SID-THR:LYS ratio was related to the model estimated steepness of the increase in BWG or decrease in FCR per unit increase in dietary SID-THR as shown in Figure 1 (for BWG) and Figure 2 (for FCR) with estimated SIDTHR:LYS requirement ratios of around $50-55 \%$ for titration trials with steep model estimated increases in BWG or decreases in FCR per unit increase in dietary SID-THR and increasing up to $85 \%$ estimated SID-THR:LYS requirement ratios at very low model estimated increases in BWG per unit increase in dietary SID-THR. The steepness of the modelled curve was also positively related to the difference between the basal level of FCR and the estimated minimum FCR $(=\mathrm{L})$ as shown in Figure 3. Furthermore, there was a significant relationship between the difference between the basal level of FCR and the estimated minimum FCR and the estimated SID-THR:LYS requirement ratio as shown in Figure 4. These relationships indicate that choice of the basal level of THR in a titration study affects the estimated SIDTHR:LYS ratio (the lower the basal level, the higher the difference between the basal level of FCR and the estimated minimum FCR and the lower the estimated SID-THR:LYS ratio). These relationships furthermore suggest that a SID-THR:LYS ratio of around $54 \%$ is the absolute minimum requirement for SID-THR resulting in a strong impairment of FCR below $54 \%$ whereas smaller improvements in FCR may be expected above $54 \%$. 


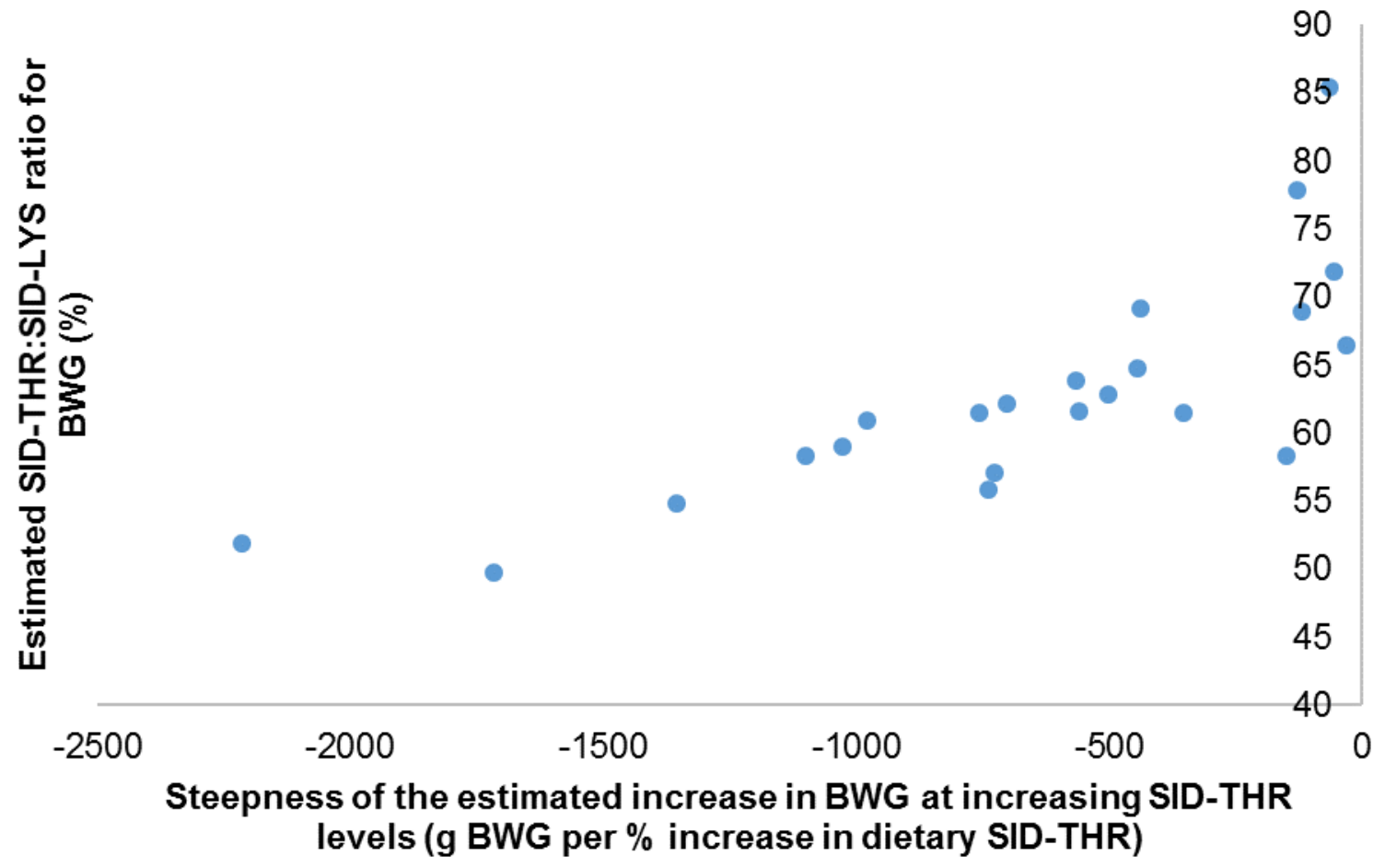

Figure 1. Relationship between the model estimated SID-THR:SID-LYS requirement ratios for maximum BWG and the steepness of the modelled increase in BWG at increasing dietary SID-THR levels (g BWG per percent increase in dietary SID-THR).

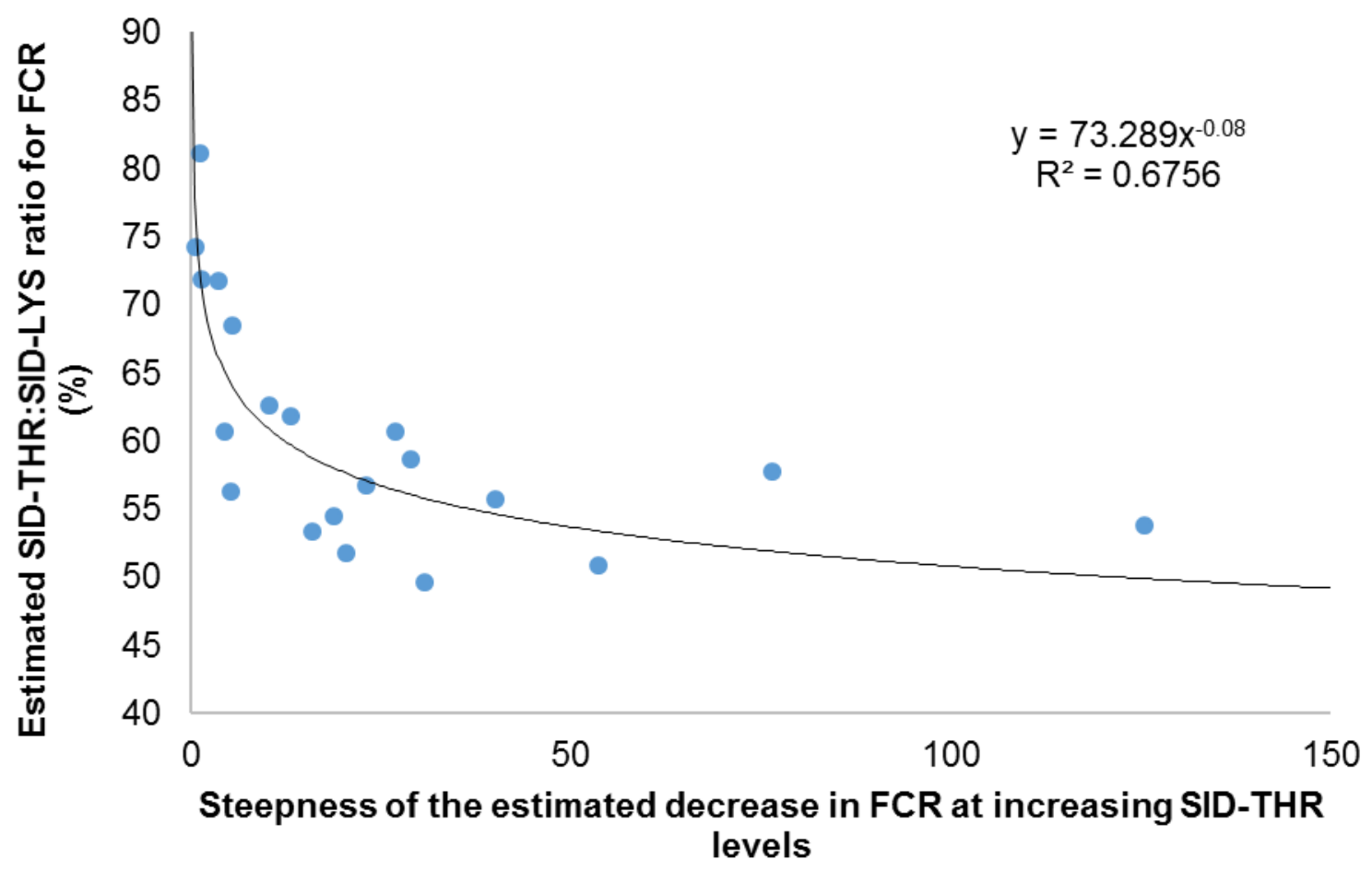

Figure 2. Relationship between the model estimated SID-THR:SID-LYS requirement ratios for minimum FCR and the steepness of the modelled decrease in FCR at increasing dietary SID-THR levels. 


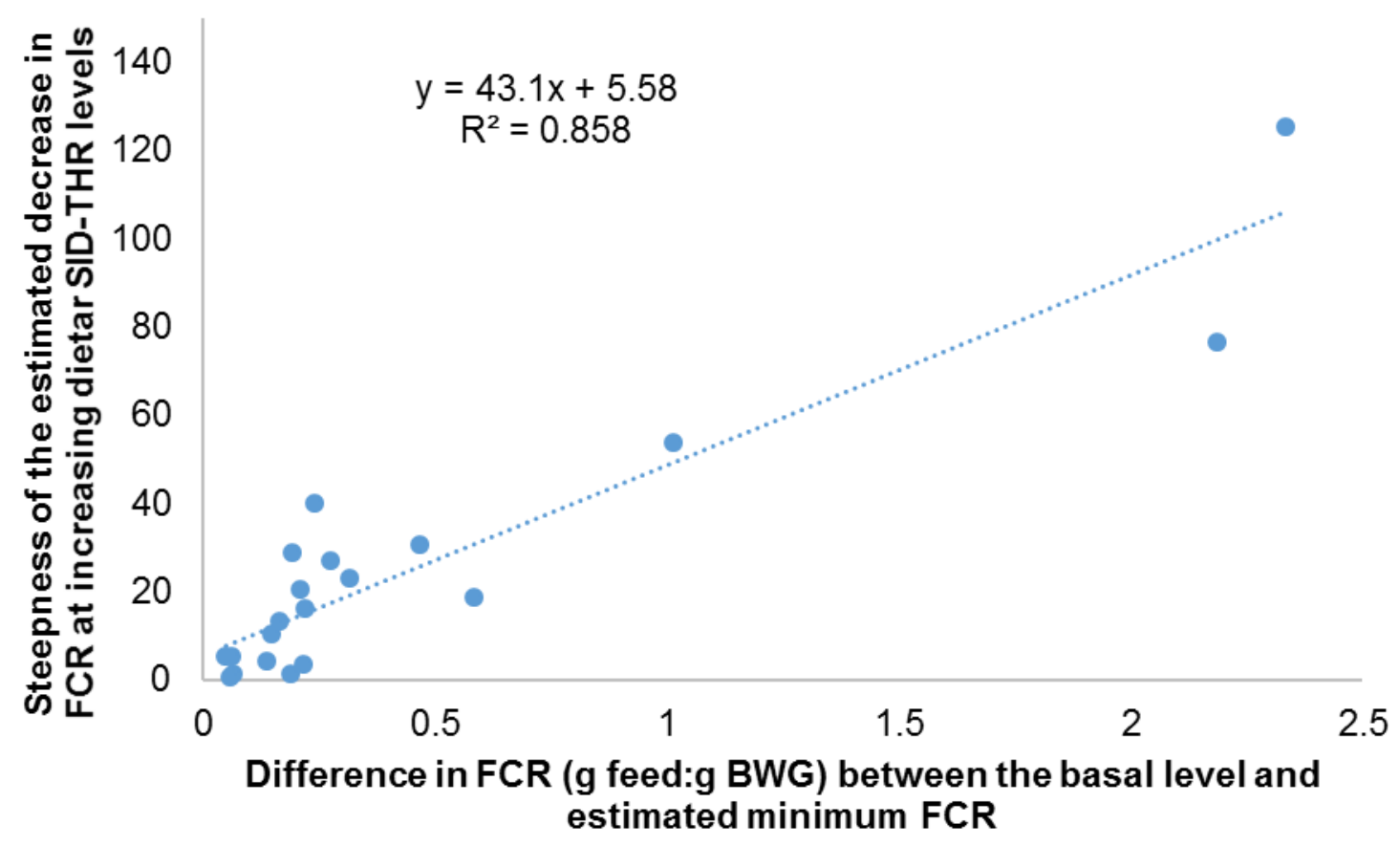

Figure 3. Relationship between the difference in FCR between the basal diet and the model estimated minimum FCR and the model estimated steepness of the decrease in FCR at increasing dietary SID-THR levels.

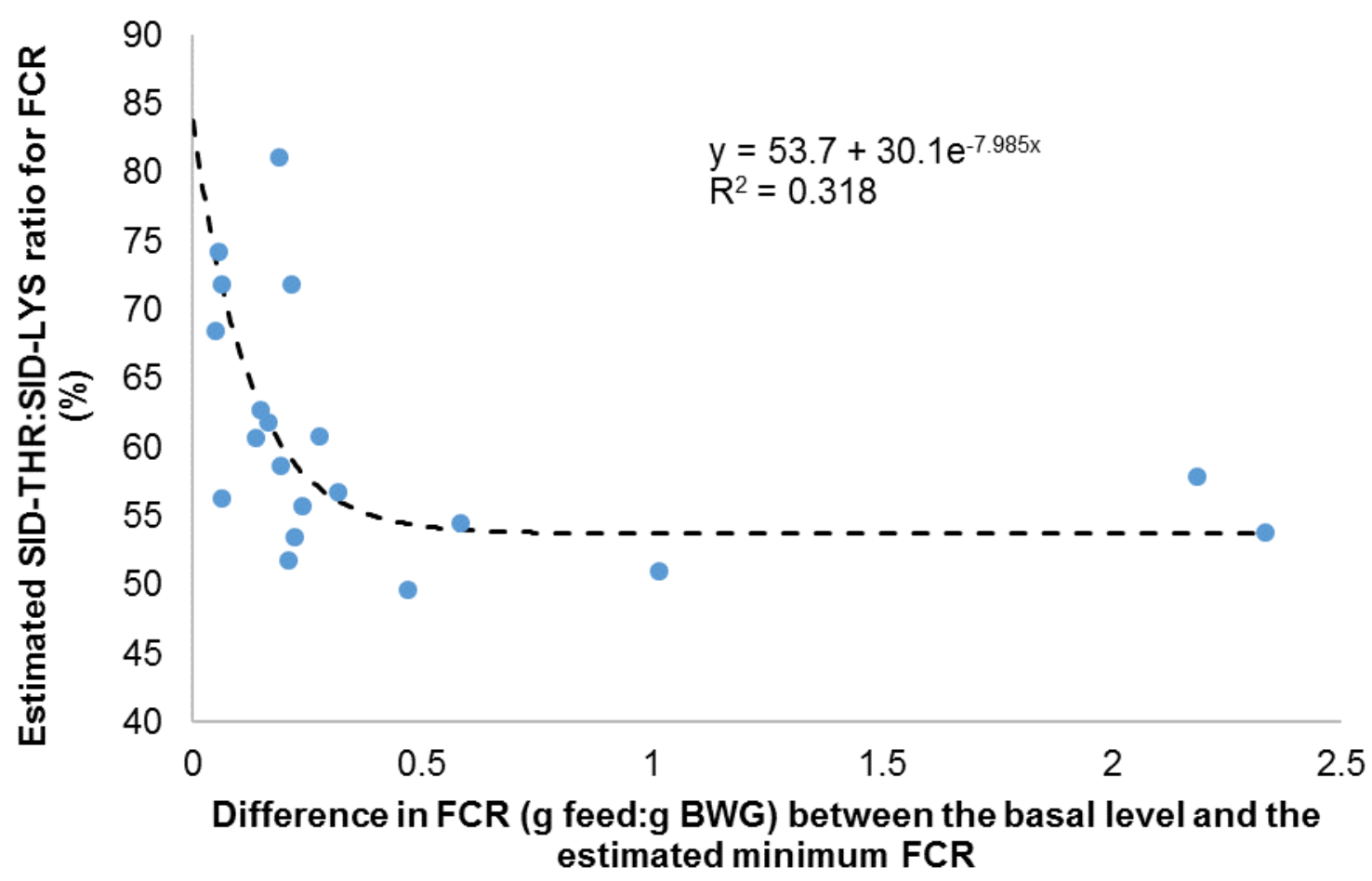

Figure 4. Relationship between the difference in FCR between the basal diet and the model estimated minimum FCR and the estimated SID-THR:SID-LYS requirement ratios for FCR.

Furthermore, it was observed that variation in estimated SID-THR:LYS requirement ratios were not significantly related to sex, age and dietary energy and protein. It is furthermore concluded that part of the variation in estimated SID-THR:LYS ratios is related to the steepness of the decrease in FCR per unit increase in dietary SID-THR and that this 
steepness is affected by the choice of the basal level of SID-THR in the diet (the lower the basal level, the higher the difference between FCR at the basal level and the estimated plateau level, the steeper the decrease in in FCR per unit increase in dietary SID-THR, and the lower the estimated SID-THR:LYS requirement ratio).

It is therefore difficult to decide what the optimal dietary SID-THR:LYS ratio is. Because of this difficulty it might be most prudent to base the dietary SID-THR:LYS ratio

recommendation on the complete dataset of SID-THR trials and correct for a (random) study effect. This results in the following recommendations:

SID-THR:LYS for BWG $=64.4 \pm 2.67 \%$ (estimate \pm St. error)

SID-THR:LYS for FCR $=62.0 \pm 2.72 \%$ (estimate \pm St. error) 


\section{Conclusions}

Based on the results of this study it is concluded that it is most prudent to base dietary SIDTHR:LYS requirement ratios on the complete dataset of SID-THR trials and correct for a (random) study effect. This results in the following SID-THR:LYS requirements:

SID-THR:LYS for BWG $=64 \%$

SID-THR:LYS for FCR $=62 \%$ 


\section{List of studies included in the meta-analysis}

Ayasan, T., F. Okan, and H. Hizli. 2009. Threonine requirement of broiler from 22-42 days. International Journal of Poultry Science 8(9):862-865.

Çiftci, I. and N. Ceylan. 2004. Effects of dietary threonine and crude protein on growth performance, carcase and meat composition of broiler chickens. British Poultry Science 45(2):280-289.

Corzo, A., W. A. Dozier lii, R. E. Loar li, M. T. Kidd, and P. B. Tillman. 2009. Assessing the threonine-to-lysine ratio of female broilers from 14 to 28 days of age. Journal of Applied Poultry Research 18(2):237-243.

Corzo, A., M. T. Kidd, W. A. Dozier lii, G. T. Pharr, and E. A. Koutsos. 2007. Dietary threonine needs for growth and immunity of broilers raised under different litter conditions. Journal of Applied Poultry Research 16(4):574-582.

Corzo, A., M. T. Kidd, and B. J. Kerr. 2003. Threonine need of growing female broilers. International Journal of Poultry Science 2(6):367-371.

Dozier, W. A., K. J. Meloche, P. B. Tillman, and Z. Jiang. 2015. Growth performance of male broilers fed diets varying in digestible threonine to lysine ratio from 1 to 14 days of age1. Journal of Applied Poultry Research 24(4):457-462.

Duarte, K. F., O. M. Junqueira, R. S. Filardi, J. C. de Siqueira, E. A. Garcia, and A. C. de Laurentiz. 2012. Threonine requirements of 22 to 42 -day-old broilers. Revista Brasileira de Zootecnia 41(1):72-79.

Kidd, M. T., A. Corzo, D. Hoehler, B. J. Kerr, S. J. Barber, and S. L. Branton. 2004. Threonine needs of broiler chickens with different growth rates. Poultry Science 83(8):1368-1375.

Kidd, M. T., B. J. Kerr, J. D. Firman, and S. D. Boling. 1996. Growth and carcass characteristics of broilers fed low-protein, threonine-supplemented diets. Journal of Applied Poultry Research 5(2):180-190.

Mack, S., D. Bercovici, G. De Groote, B. Leclercq, M. Lippens, M. Pack, J. B. Schutte, and S. Van Cauwenberghe. 1999. Ideal amino acid profile and dietary lysine specification for broiler chickens of 20 to 40 days of age. British Poultry Science 40(2):257-265.

Mehri, M., H. Nassiri-Moghaddam, H. Kermanshahi, and M. Danesh-Mesgaran. 2010. Digestible threonine needs of straight-run broiler during the growing period. Journal of Animal and Veterinary Advances 9(16):2190-2193.

Neto, R. C. L., F. G. P. Costa, R. L. Furlan, P. E. N. Givisiez, C. C. Goulart, C. F. S. Oliveira, S. A. N. Morais, R. M. Bezerra, and M. R. Lima. 2012. Levels of digestible threonine for male broilers from 1 to 7 days of age. Journal of Applied Poultry Research 21(4):757-763.

Rosa, A. P., G. M. Pesti, H. M. Edwards Jr, and R. I. Bakalli. 2001. Threonine requirements of different broiler genotypes. Poultry Science 80(12):1710-1717.

\section{References}

Blok and Dekker. 2017. Table 'Standardized ileal digestibility of amino acids in feedstuffs for poultry'. CVB Documentation report nr. 61.

Spek, J.W. 2018. Standardized ileal digestible lysine requirement for broilers. CVB Documentation report n. 62.

Veldkamp, T., J.W. van Riel, R.A. Dekker, S. Khalaji, V. Khaksar, H. Hashemipour, M.M. van Krimpen, and M.C. Blok. 2016. Estimating requirement values for apparent faecal digestible and standardised ileal digestible threonine in broilers by a meta-analysis approach. 


\section{Appendix A. Relationship between dietary SID-THR supply and performance parameters FCR and BWG for the various titration trials.}

On the x-axis of the Figures the dietary THR concentration (\%) is given and on the $y$-axis of the Figures the FCR (left hand Figures) and BWG (right hand figures) are given. The closed circles are the observed values and the 'c' symbols are the fitted values.

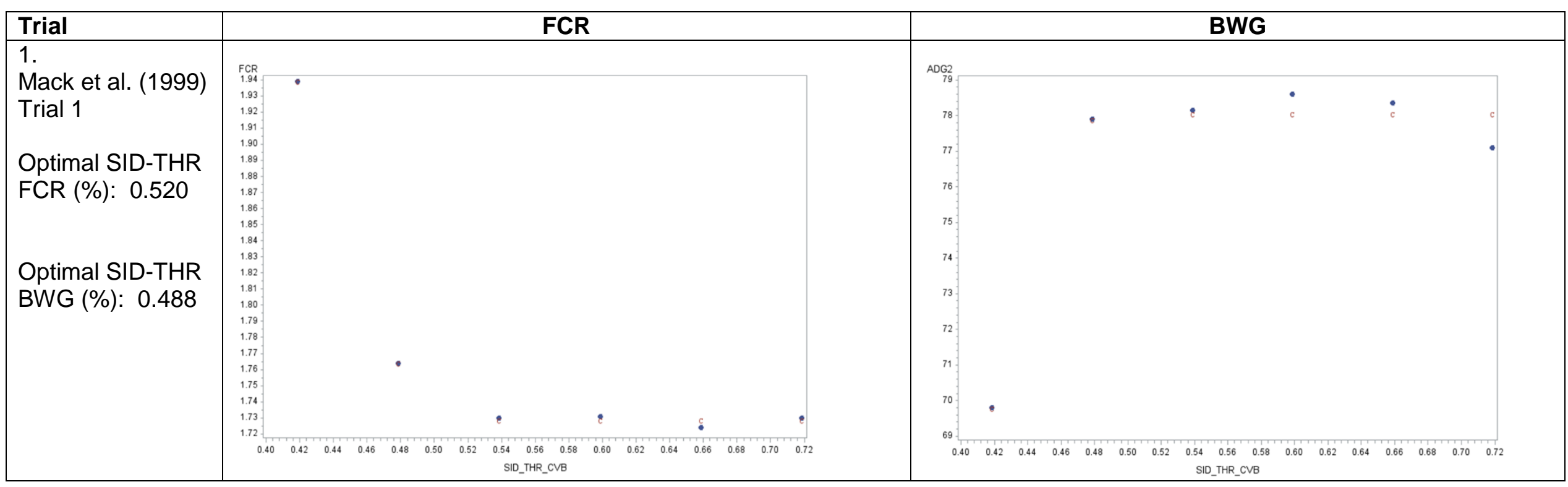




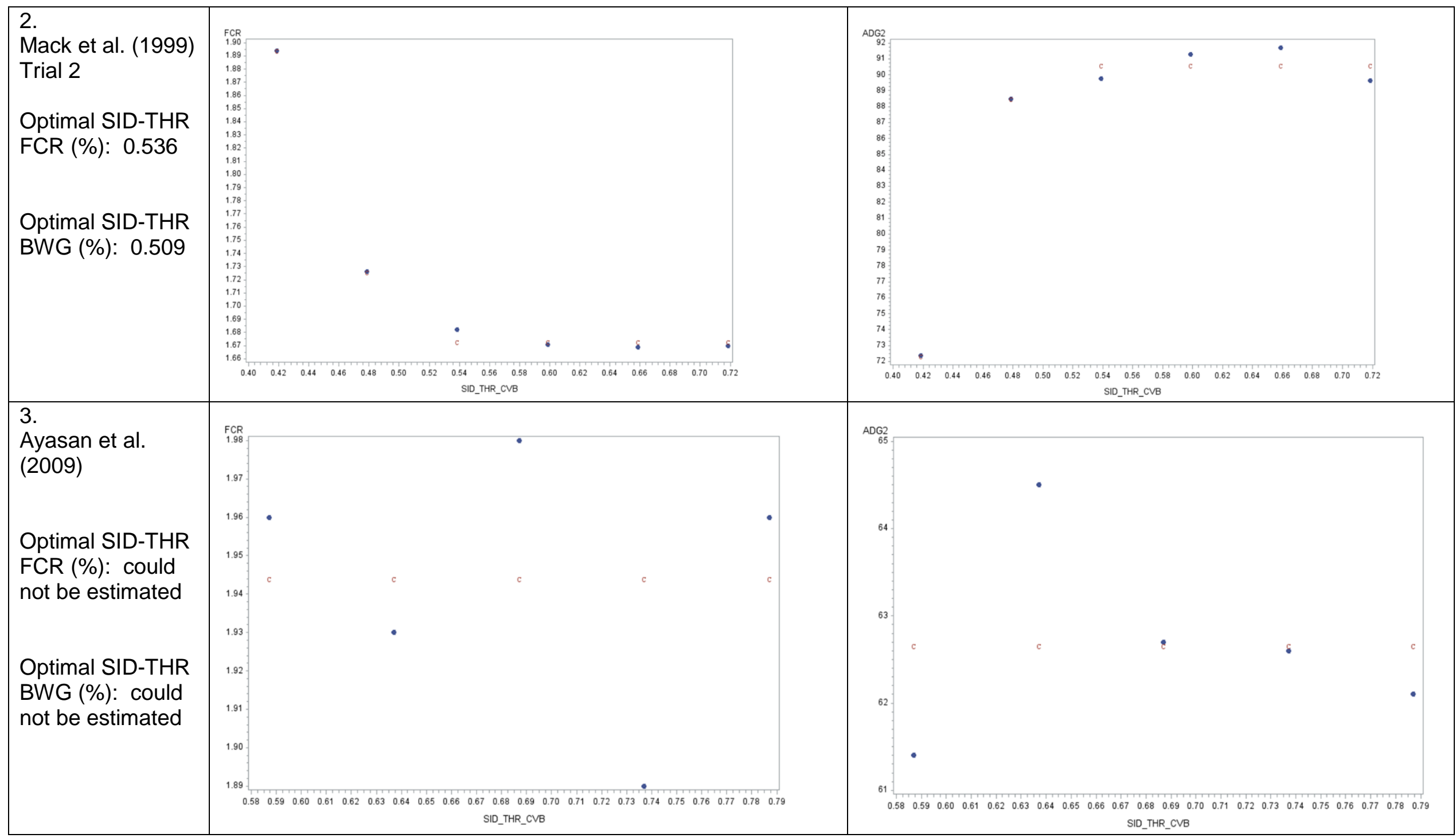




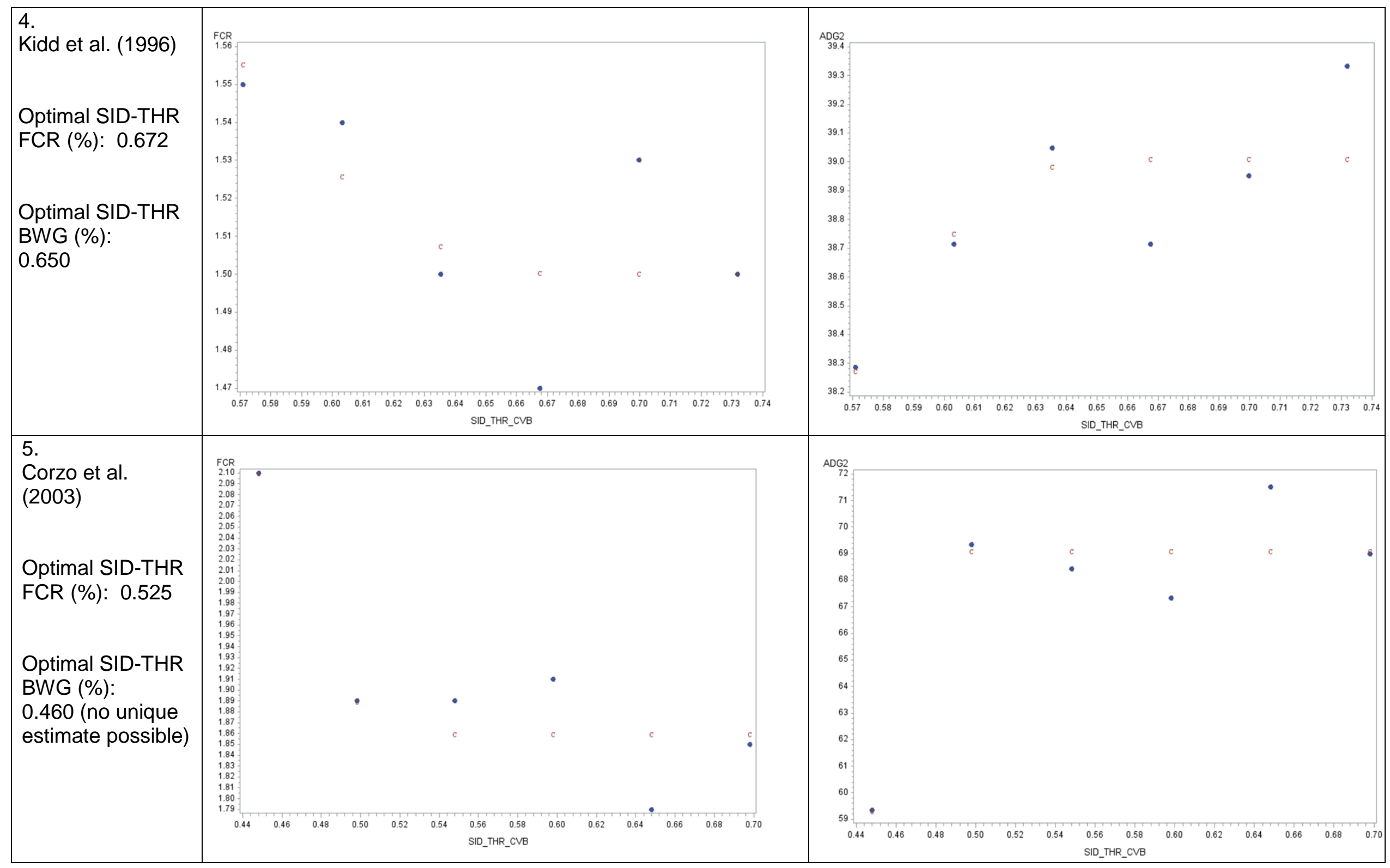




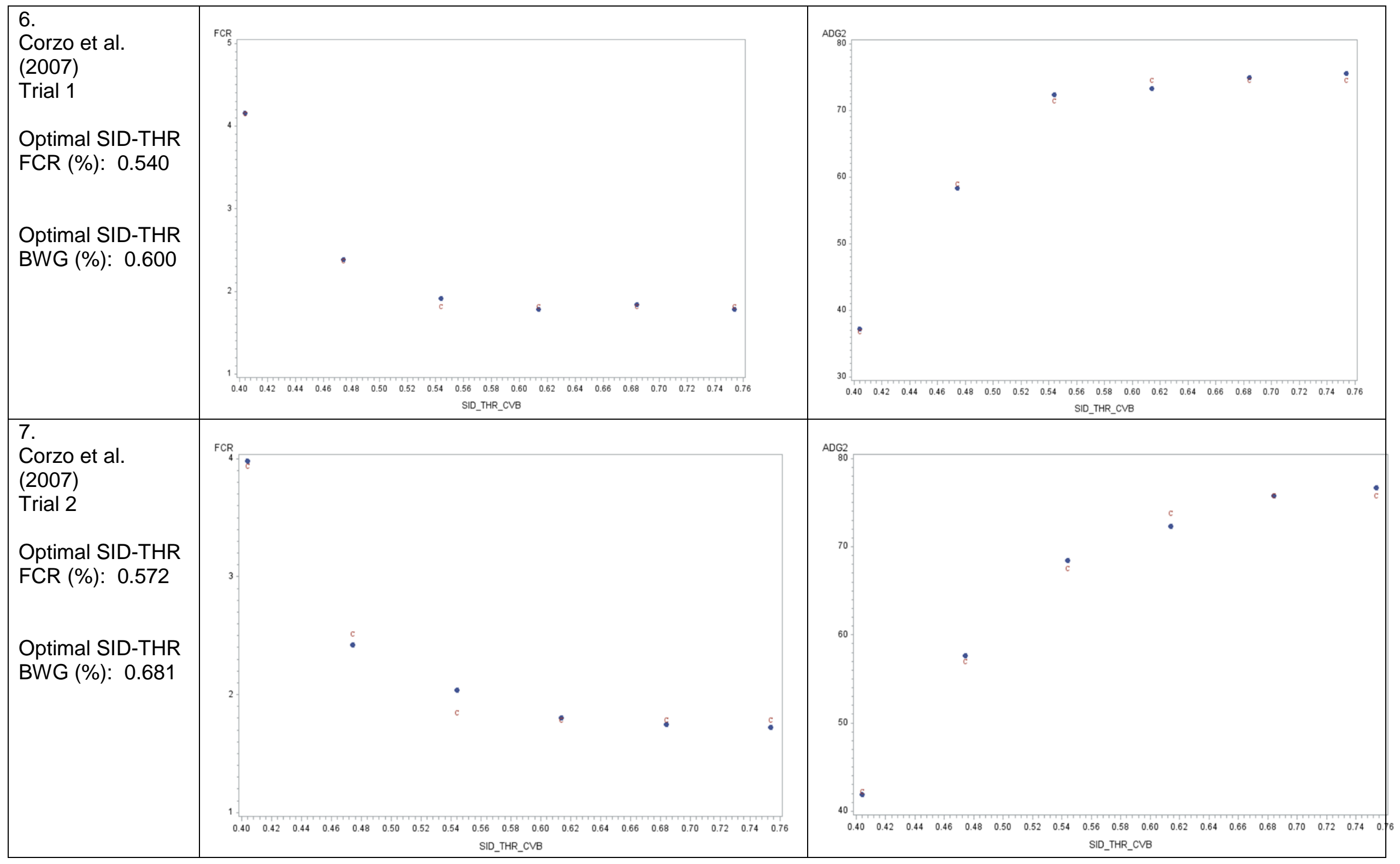




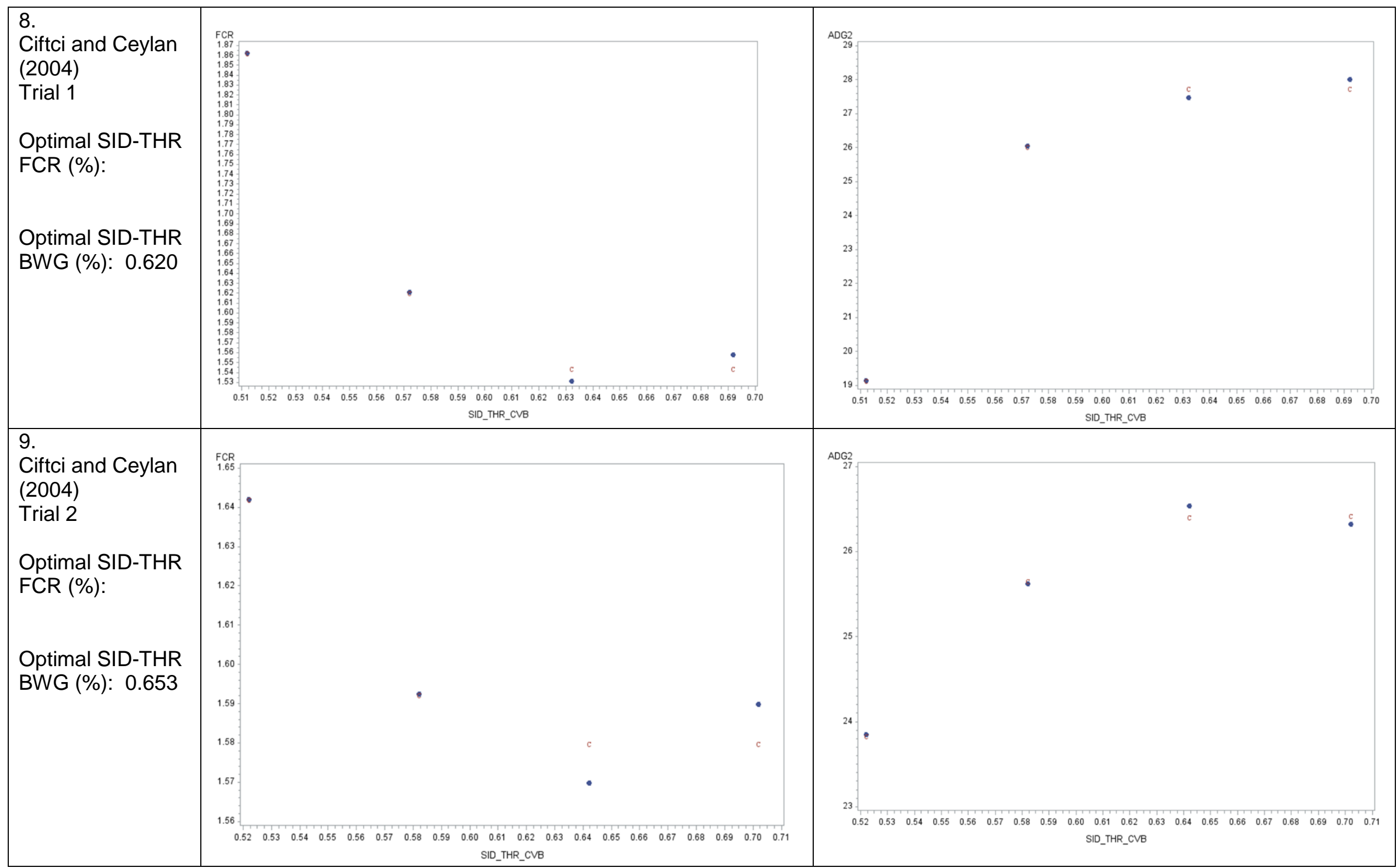




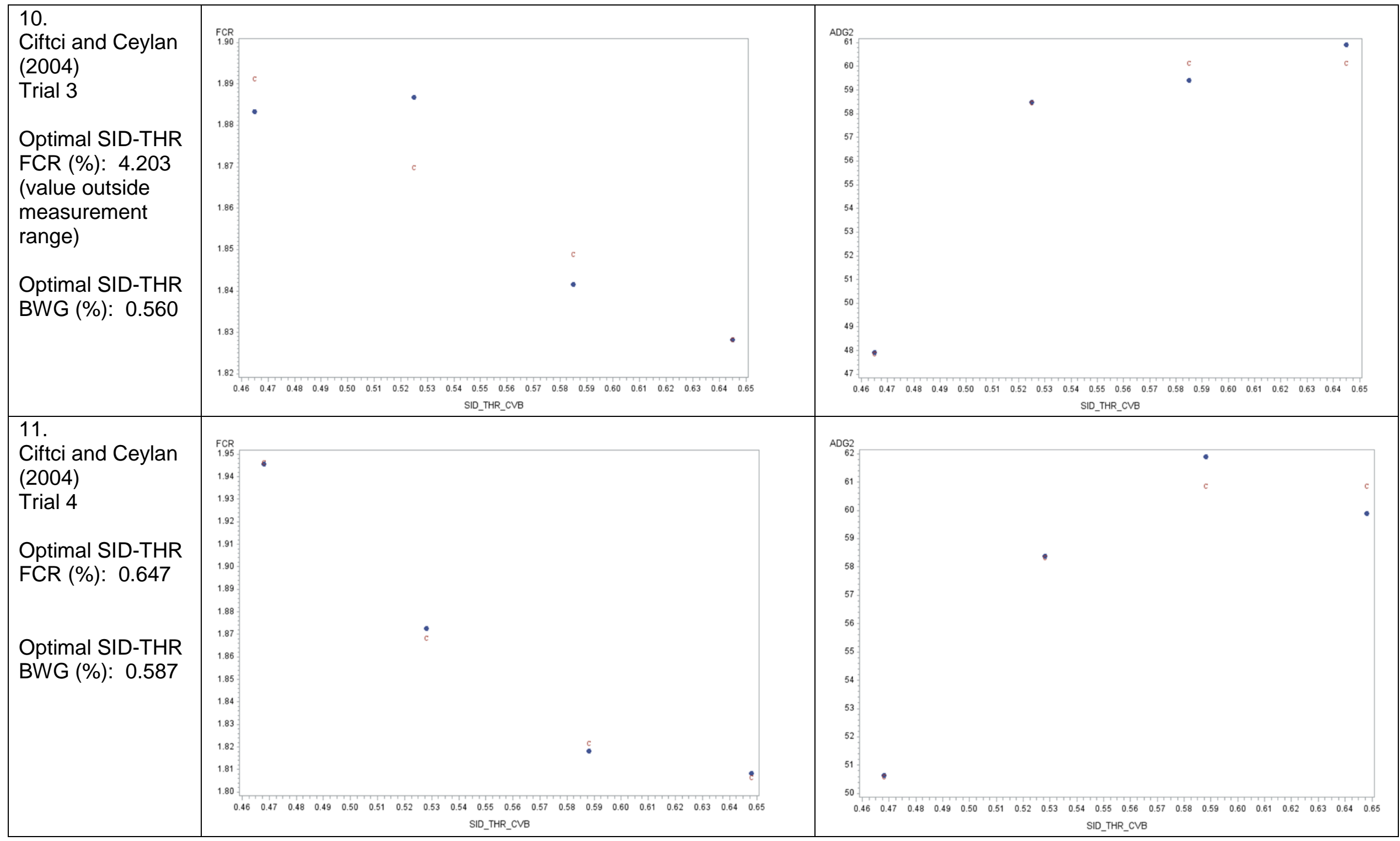




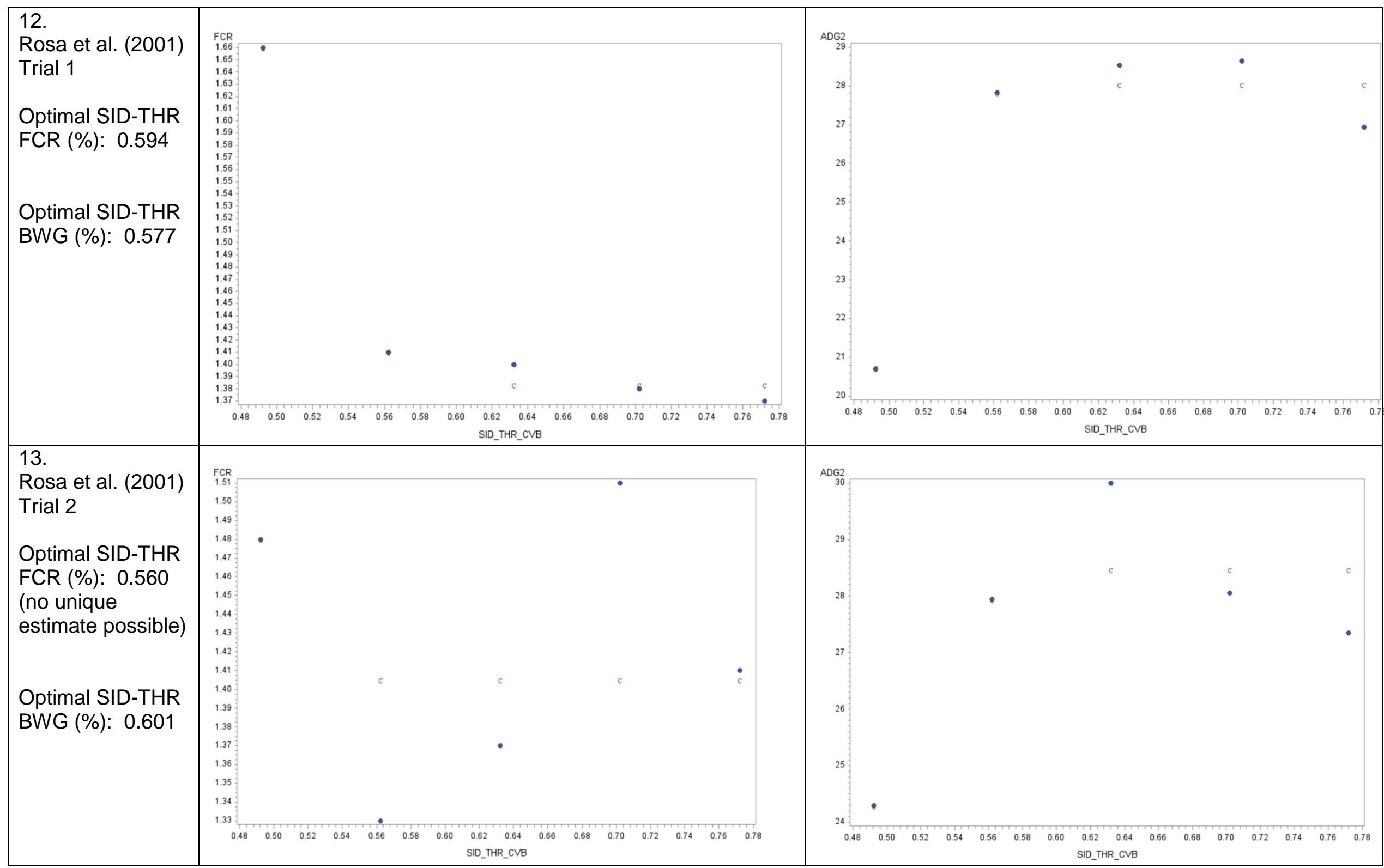




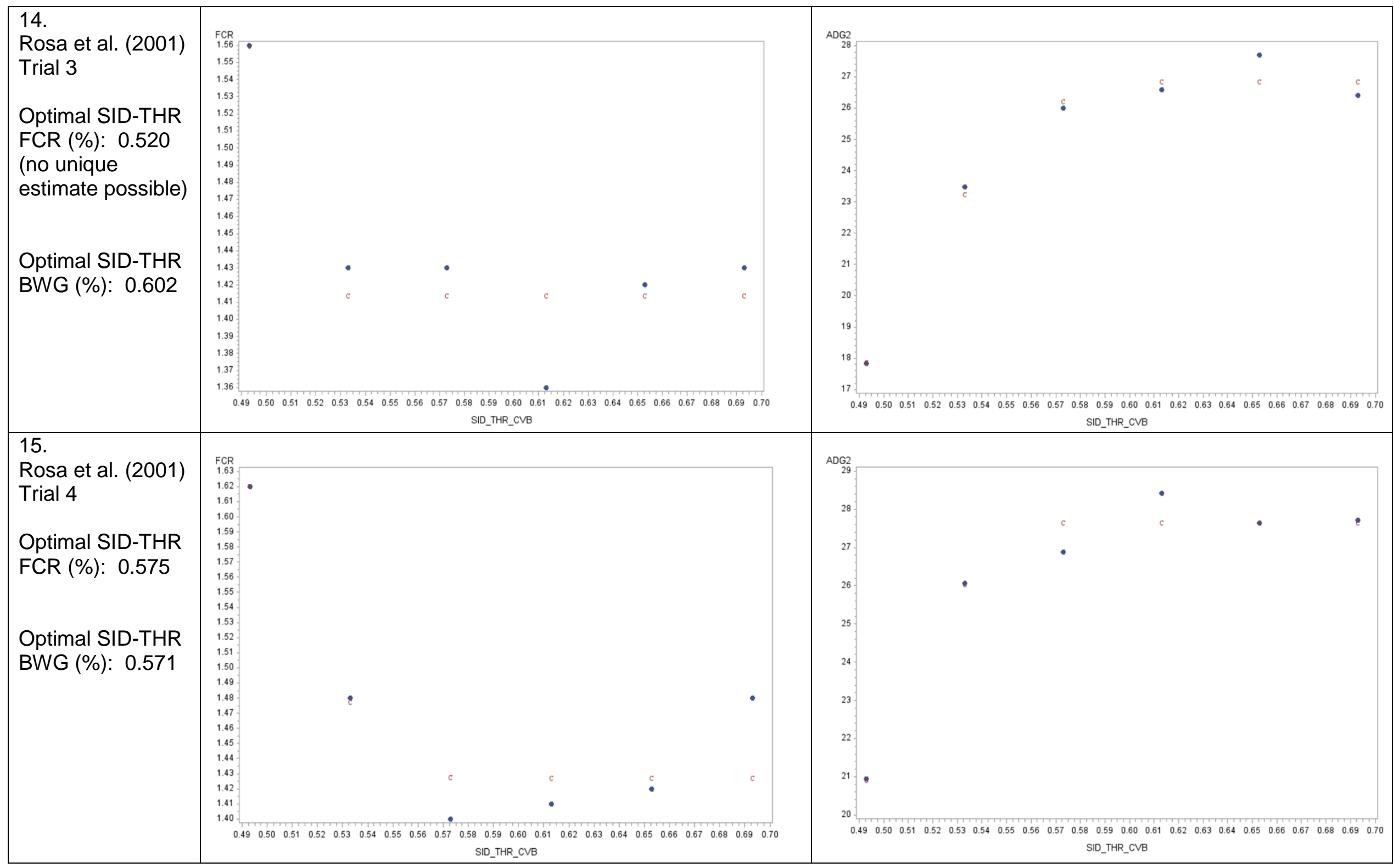




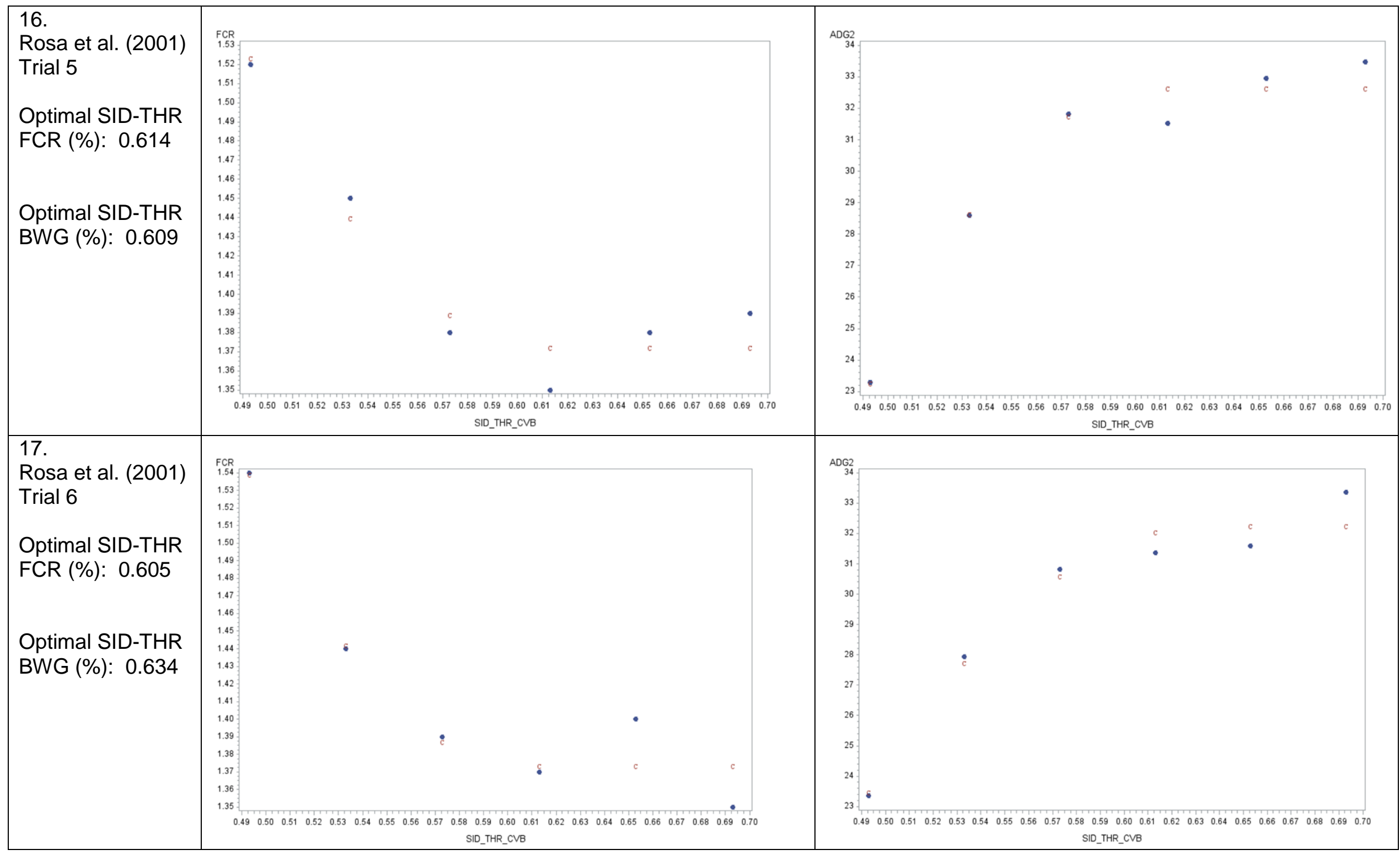




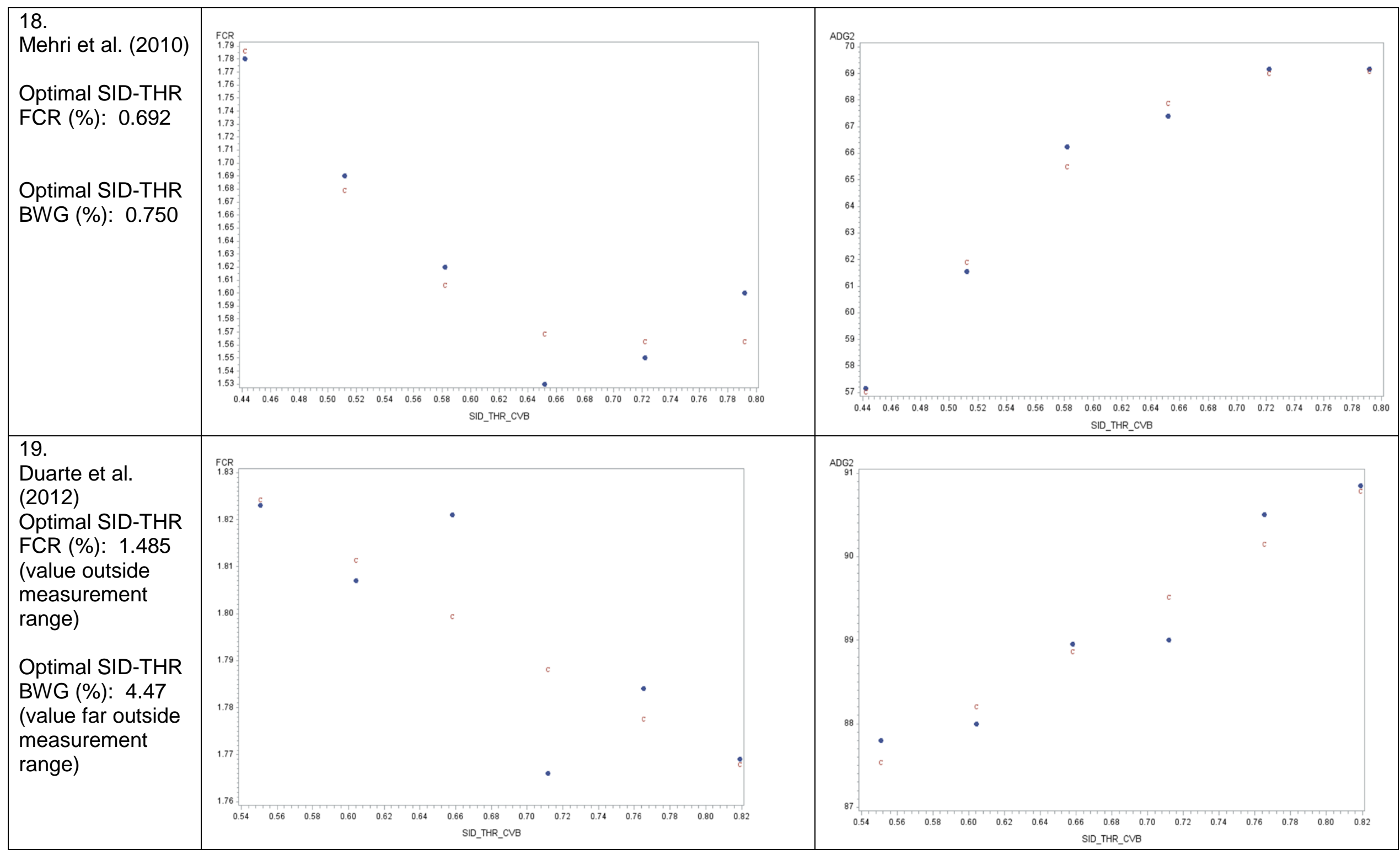




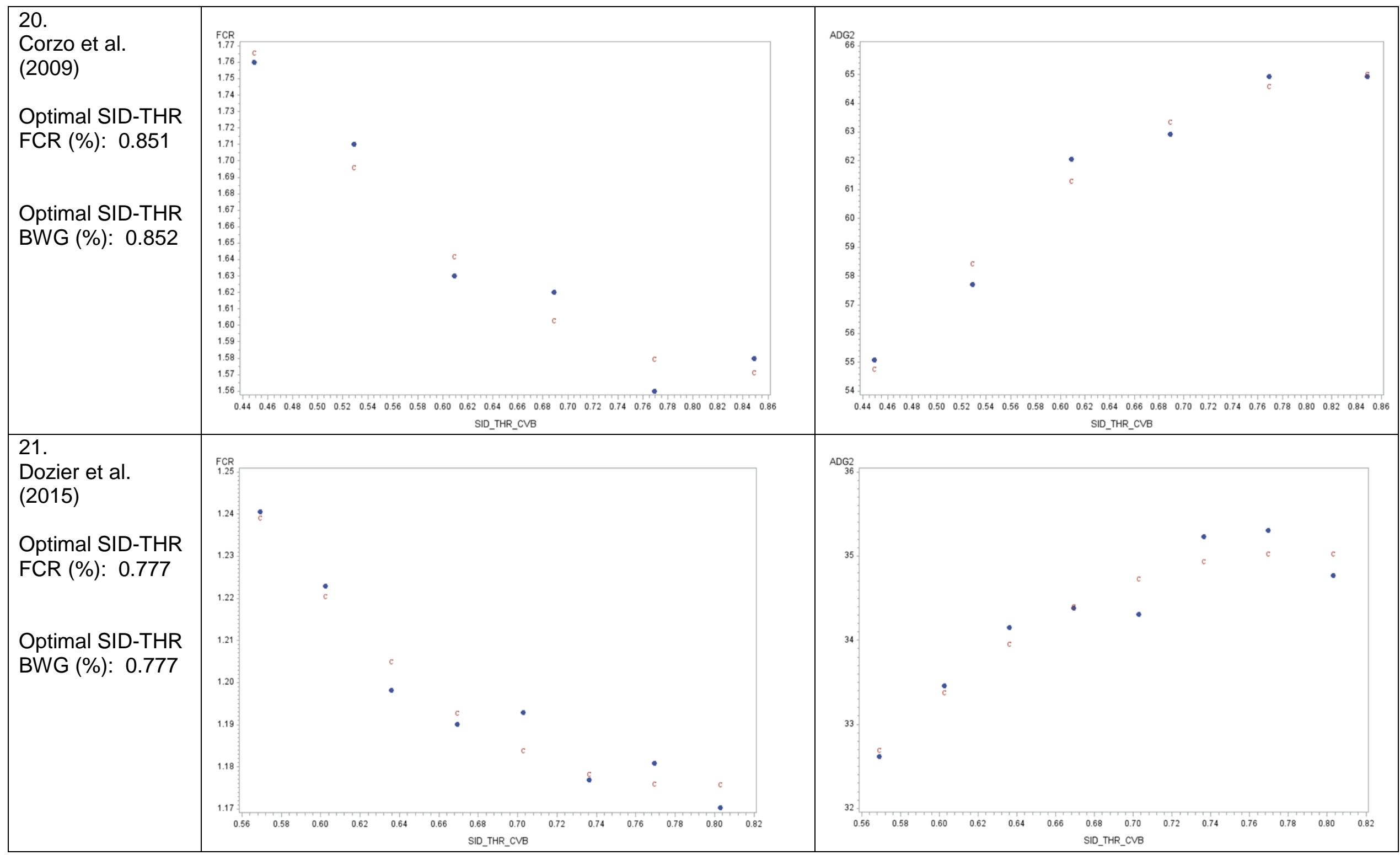




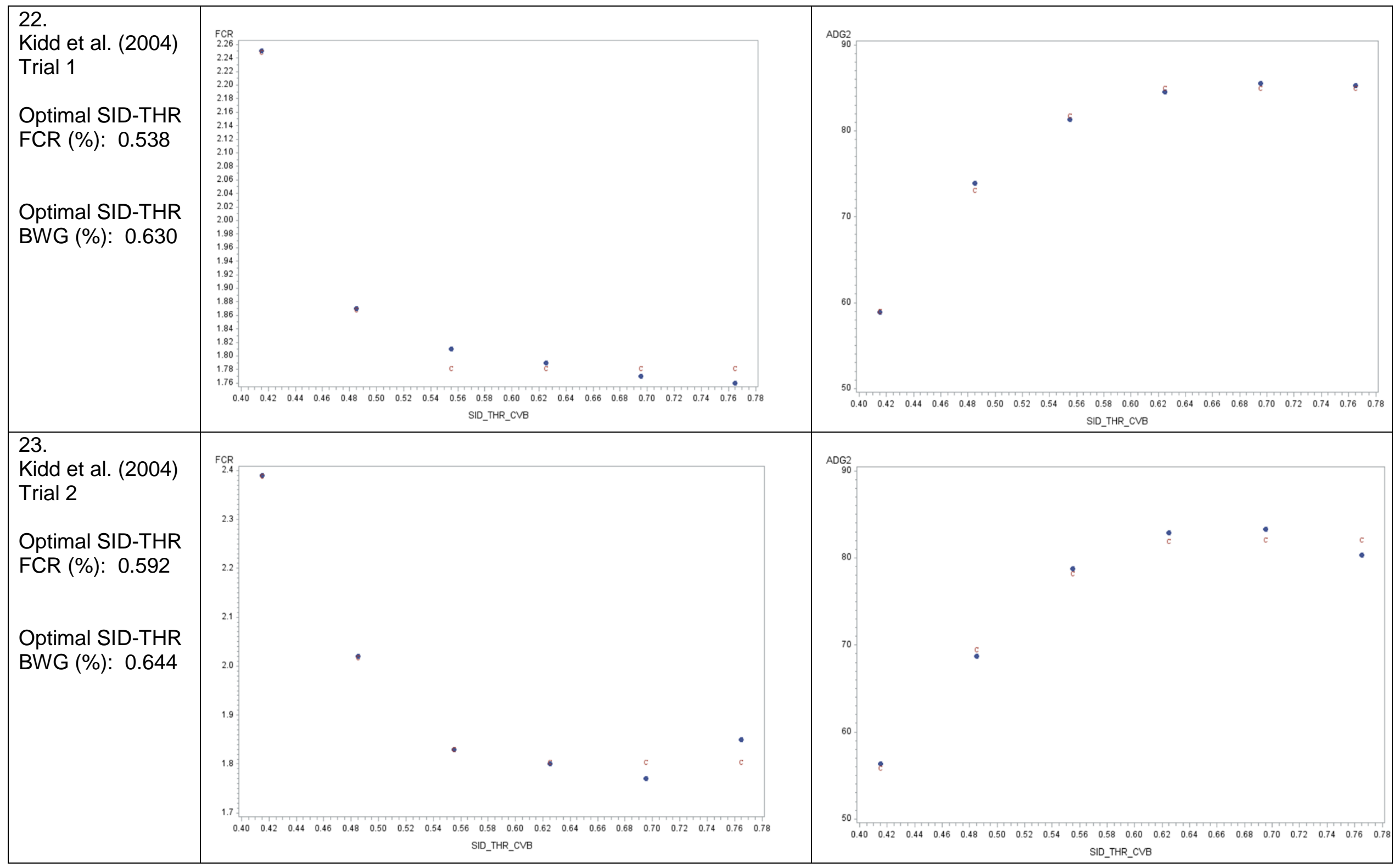




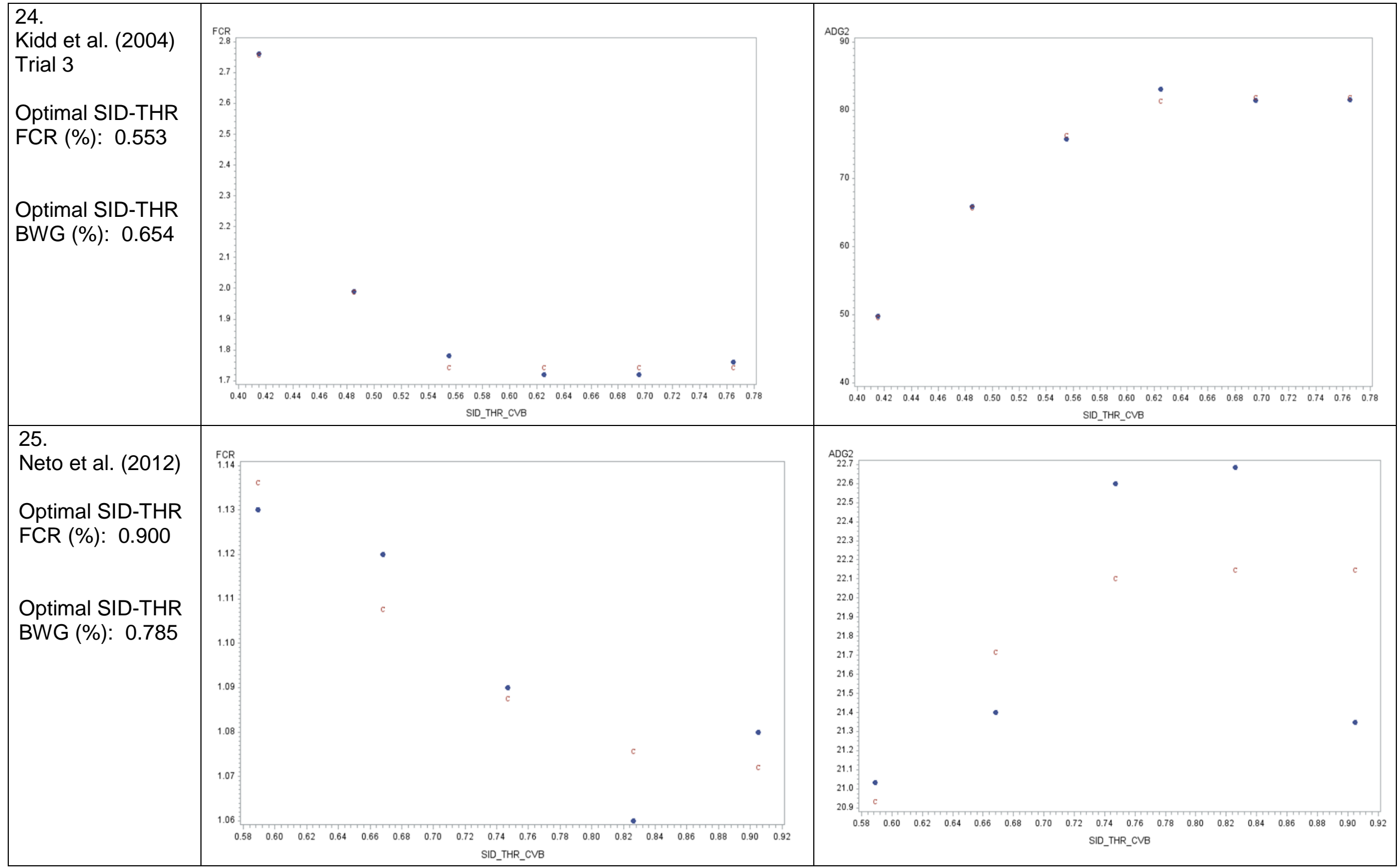




\section{Appendix B. SID-THR model estimates using the quadratic broken-line model for minimum FCR and maximum BWG}

\begin{tabular}{lrrrrrrr}
\multicolumn{6}{c}{ SID-THR model estimates using the quadratic broken-line model for minimum FCR } \\
\hline Trial nr. & Estimate & Std. Err. & Estimate & Std. Err. & Estimate & Std. & $\mathbf{R}^{\mathbf{2}}$ \\
\hline 1 & $\mathbf{L}$ & $\mathbf{L}$ & $\mathbf{R}$ & $\mathbf{R}$ & $\mathbf{U}$ & Err. U & \\
2 & 1.729 & 0.0016 & 0.520 & 0.0035 & 20.4 & 1.44 & 0.999 \\
3 & 1.673 & 0.0030 & 0.536 & 0.0071 & 16.0 & 2.00 & 0.997 \\
4 & & & & & & & \\
5 & 1.500 & 0.0159 & 0.672 & 0.0969 & 5.4 & 10.77 & 0.540 \\
6 & 1.860 & 0.0265 & 0.525 & 0.0410 & 40.1 & 42.91 & 0.847 \\
7 & 1.828 & 0.0309 & 0.540 & 0.0079 & 125.4 & 15.19 & 0.997 \\
8 & 1.794 & 0.0747 & 0.572 & 0.0226 & 76.5 & 21.26 & 0.986 \\
9 & 1.545 & 0.0131 & 0.630 & 0.0159 & 23.0 & 6.28 & 0.995 \\
10 & 1.580 & 0.0100 & 0.631 & 0.0582 & 5.3 & 5.61 & 0.930 \\
11 & 1.221 & 37.0445 & 4.203 & 211.7000 & 0.0 & 2.79 & 0.846 \\
12 & 1.807 & 0.0057 & 0.647 & 0.0177 & 4.4 & 0.83 & 0.997 \\
13 & 1.383 & 0.0088 & 0.594 & 0.0148 & 26.8 & 7.76 & 0.992 \\
14 & 1.405 & 0.0386 & 0.560 & & 16.3 & 18.77 & 0.201 \\
15 & 1.414 & 0.0136 & 0.520 & & 200.3 & 45.83 & 0.827 \\
16 & 1.428 & 0.0183 & 0.575 & 0.0338 & 29.0 & 25.02 & 0.885 \\
17 & 1.372 & 0.0109 & 0.614 & 0.0296 & 10.4 & 5.34 & 0.945 \\
18 & 1.374 & 0.0118 & 0.605 & 0.0279 & 13.1 & 6.79 & 0.945 \\
19 & 1.564 & 0.0222 & 0.692 & 0.0752 & 3.6 & 2.19 & 0.922 \\
20 & 1.710 & 0.6650 & 1.485 & 6.4017 & 0.1 & 1.05 & 0.686 \\
21 & 1.572 & 0.0178 & 0.851 & 0.0863 & 1.2 & 0.49 & 0.963 \\
22 & 1.176 & 0.0045 & 0.777 & 0.0379 & 1.5 & 0.53 & 0.951 \\
23 & 1.783 & 0.0111 & 0.538 & 0.0131 & 30.7 & 6.68 & 0.992 \\
24 & 1.806 & 0.0185 & 0.592 & 0.0209 & 18.7 & 4.59 & 0.988 \\
25 & 1.745 & 0.0150 & 0.553 & 0.0089 & 53.6 & 7.24 & 0.997 \\
\hline & 1.072 & 0.0148 & 0.900 & 0.1720 & 0.7 & 0.71 & 0.848 \\
\hline
\end{tabular}


SID-THR model estimates using the quadratic broken-line model for maximum BWG

\begin{tabular}{lrrrrrrr}
\hline Trial nr. & Estimate & Std. Err. & Estimate & Std. Err. & Estimate & Std. & $\mathbf{R}^{\mathbf{2}}$ \\
& $\mathbf{L}$ & $\mathbf{L}$ & $\mathbf{R}$ & $\mathbf{R}$ & $\mathbf{U}$ & Err. $\mathbf{~}$ & \\
\hline 1 & 78.1 & 0.33 & 0.488 & 0.0265 & -1715 & 1290.5 & 0.977 \\
2 & 90.6 & 0.53 & 0.509 & 0.0128 & -2214 & 630.3 & 0.988 \\
3 & & & & & & & \\
4 & 39.0 & 0.14 & 0.650 & 0.0589 & -118 & 182.1 & 0.685 \\
5 & 69.1 & 0.69 & 0.460 & & -67940 & 11668.6 & 0.895 \\
6 & 74.7 & 0.66 & 0.600 & 0.0121 & -979 & 125.7 & 0.997 \\
7 & 75.9 & 0.80 & 0.681 & 0.0188 & -437 & 60.5 & 0.995 \\
8 & 27.7 & 0.27 & 0.620 & 0.0112 & -738 & 152.5 & 0.997 \\
9 & 26.4 & 0.14 & 0.653 & 0.0220 & -150 & 49.3 & 0.993 \\
10 & 60.2 & 0.76 & 0.560 & 0.0211 & -1354 & 587.8 & 0.989 \\
11 & 60.9 & 1.00 & 0.587 & 0.0378 & -726 & 466.5 & 0.973 \\
12 & 28.0 & 0.55 & 0.577 & 0.0443 & -1027 & 1053.6 & 0.959 \\
13 & 28.5 & 0.79 & 0.601 & 0.0877 & -354 & 569.1 & 0.780 \\
14 & 26.9 & 0.34 & 0.602 & 0.0147 & -757 & 212.7 & 0.984 \\
15 & 27.7 & 0.31 & 0.571 & 0.0160 & -1100 & 467.3 & 0.969 \\
16 & 32.7 & 0.47 & 0.609 & 0.0199 & -702 & 253.1 & 0.972 \\
17 & 32.3 & 0.57 & 0.634 & 0.0278 & -443 & 179.0 & 0.965 \\
18 & 69.1 & 0.45 & 0.750 & 0.0298 & -127 & 24.1 & 0.992 \\
19 & 112.1 & 334.30 & 4.472 & 55.2012 & -2 & 23.3 & 0.936 \\
20 & 65.1 & 0.66 & 0.852 & 0.0606 & -63 & 18.1 & 0.981 \\
21 & 35.0 & 0.22 & 0.777 & 0.0498 & -54 & 25.8 & 0.918 \\
22 & 85.1 & 0.40 & 0.630 & 0.0111 & -559 & 60.3 & 0.998 \\
23 & 82.2 & 0.93 & 0.644 & 0.0264 & -503 & 119.8 & 0.988 \\
24 & 81.9 & 0.71 & 0.654 & 0.0165 & -566 & 80.4 & 0.996 \\
25 & 22.2 & 0.54 & 0.785 & 0.2879 & -32 & 93.9 & 0.460 \\
\hline
\end{tabular}

